Pengaruh Konsentrasi Karagenan dan Tepung Terigu - Winifati, dkk Jurnal Pangan dan Agroindustri Vol.8 No.2: 86-94, April 2020

\title{
PENGARUH KONSENTRASI KARAGENAN DAN TEPUNG TERIGU TERHADAP KARAKTERISTIK FISIK FRUIT LEATHER APEL ANNA (Malus domestica)
}

\section{The Influence Of Carrageenan And Wheat Flour Concentration on Physical Characteristics of Anna Apple (Malus domestica) Fruit Leather}

\author{
Yossy Eka Winifati, Ahmad Zaki Mubarok* \\ Jurusan Teknologi Hasil Pertanian, FTP Universitas Brawijaya \\ JI.Veteran, Malang 65145 \\ *Penulis Korespondensi, email: ahmadzaki@ub.ac.id
}

\begin{abstract}
ABSTRAK
Apel (Malus domestica) merupakan buah dengan kandungan pektin dan senyawa antioksidan yang tinggi. Kota Batu terkenal sebagai penghasil apel dimana apel Anna menjadi salah satu varietas yang cukup berhasil dibudidayakan di kota tersebut. Namun dibandingkan varietas lainnya apel Anna memiliki umur simpan yang paling singkat. Salah satu cara untuk memperpanjang umur simpan apel Anna yaitu dengan mengolahnya menjadi fruit leather. Fruit leather berbahan baku apel Anna memiliki plastisitas yang kurang baik dan mudah robek sehingga perlu penambahan karagenan sebagai gelling agent dan tepung terigu sebagai filler. Penelitian bertujuan menganalisis pengaruh konsentrasi karagenan dan tepung terigu terhadap sifat fisik fruit leather berbahan baku apel Anna. Percobaan dilaksanakan dengan Rancangan Acak Kelompok dengan dua faktor, dimana faktor pertama adalah konsentrasi karagenan $(0 \% ; 0.5 \% ; 1 \%)$ dan faktor kedua adalah konsentrasi tepung terigu (1\%; $2 \% ; 3 \%)$. Perlakuan terbaik fruit leather apel Anna yaitu dengan penambahan karagenan $1 \%$ dan tepung terigu $3 \%$.
\end{abstract}

Kata Kunci: Apel Anna, Fruit leather, Karagenan, Tepung terigu

\section{ABSTRACK}

Apple (Malus domestica) have high content of pectin and antioxidants. Anna apple is one of the varieties that have been successfully cultivated in Batu City, which has a shorter shelf life compared to other varieties. One way to extend the shelf life of apple is by processing them into a fruit leather. Fruit leather made from Anna apples has weak plasticity so it needs addition of carrageenan as a gelling agent and flour as a filler. The purpose of this study was to analyze the effect of carrageenan and wheat flour concentration on physical properties of apple fruit leather. Two factors experiment with Randomized Block Design, where carrageenan concentration $(0 \% ; 0.5 \% ; 1 \%)$ as the first factor and concentration of wheat flour (1\%;2\%; $3 \%)$ as the second factor. The optimum formulation for Anna apple fruit leather with addition of carrageenan $1 \%$ and wheat flour $3 \%$.

Keywords: Anna apple, Carrageenan, Fruit leather, Wheat flour

\section{PENDAHULUAN}

Apel (Malus domestica) salah satu buah yang populer dan digemari masyarakat. Buah apel memiliki kandungan nutrisi yang berguna bagi kesehatan, seperti vitamin $\mathrm{C}$, pektin yang berperan sebagai serat, dan kuersetin sebagai bahan antikanker dan antiradang (Baskara, 2010). Salah satu daerah yang paling terkenal sebagai penghasil buah apel adalah Kota Batu. Data dari Badan Pusat Statistik Kota Batu (2018) menyatakan pada triwulan IV tahun 2016 di Kota Batu terdapat 2.1 juta pohon apel dan dari jumlah tersebut menghasilkan buah sebanyak 146 ribu ton per tahun. Varietas apel yang cukup berhasil 
dibudidayakan adalah Apel Manalagi, Romebeauty, Anna, Princess Noble, dan Wangli/Lali jiwo. Sama seperti buah-buahan lainnya, apel juga akan terus melanjutkan proses metabolisme pasca panen. Seiring berjalannya kegiatan metabolisme, apel akan mengalami perubahan fisik dan degradasi komponen kimia. Dibandingkan varietas lainnya, apel Anna memiliki umur simpan yang paling singkat (Tawali dan Zainal, 2004). Salah satu upaya memperpanjang umur simpan dan menambah nilai ekonomis yaitu dengan mengolahnya menjadi fruit leather.

Kendala yang sering muncul pada pembuatan fruit leather adalah plastisitasnya yang kurang baik (Historiasih, 2010). Karagenan digunakan dalam industri pangan sebagai pengental dan penstabil (Agustin dan Putri, 2013), polisakarida larut air ini juga dapat digunakan sebagai gelling agent untuk memodifikasi produk fruit leather. Penelitian sebelumnya menunjukkan bahwa penggunaan karagenan sebesar $0.6 \%$ memberikan pengaruh terhadap tekstur fruit leather dari bahan baku nanas dan wortel (Sidi et al., 2014). Hidrokoloid telah banyak dimanfaatkan sebagai agen pembentuk gel atau pengental yang mampu mengikat molekul air untuk modifikasi tekstur pada produk makanan (Rascon-Diaz et al., 2010). Selain itu, adanya proses pengeringan dengan suhu tinggi dan waktu yang cukup lama pada pembuatan fruit leather dapat menyebabkan hilangnya air atau penguapan secara berlebihan pada produk yang menyebabkan ikatan antar molekul semakin erat dan terbentuk tekstur seperti kertas yang mudah robek. Diduga, penambahan tepung terigu mampu memperbaiki tekstur fruit leather yang mudah sobek seperti kertas. Dalam penelitian ini, tepung terigu digunakan sebagai filler karena mengandung banyak zat pati yang meningkatkan daya ikat air sehingga tekstur menjadi padat. Penambahan sedikit pati gandum memungkinkan fruit leather memiliki struktur seperti jeli (Yilmaz et al., 2017). Berdasarkan hal itu, maka dilakukan inovasi pembuatan fruit leather dengan cara menambahkan karagenan dan tepung terigu dengan berbagai konsentrasi untuk menghasilkan fruit leather dengan karakteristik fisik yang baik.

\section{BAHAN DAN METODE}

\section{Bahan}

Bahan untuk membuat produk fruit leather apel adalah buah apel Anna yang diperoleh dari Pasar Batu, kappa karagenan dari toko bahan kimia Makmur Sejati Malang, tepung terigu (Segitiga Biru) dan gula pasir (Gulaku) dari toko di Kota Malang. Bahan lain untuk analisis kimia didapatkan dari Krida Tama Malang, diantaranya petroleum eter, $\mathrm{H}_{2} \mathrm{SO}_{4}$, methyl red, indikator $\mathrm{PP}, \mathrm{NaOH}, \mathrm{HCl}, \mathrm{K}_{2} \mathrm{SO}_{4}$, kertas saring Whatman no $40, \mathrm{NaOH}$, etanol, dan metanol p.a (pro analysis). Bahan kimia lainnya seperti DPPH, tablet kjeldahl, asam borat didapatkan dari Laboratorium Kimia dan Biokimia Pangan, Fakultas Teknologi Pertanian, Universitas Brawijaya.

\section{Alat}

Alat yang dipakai untuk pembuatan leather apel antara lain pisau, baskom, talenan, dandang (Jawa), kompor gas (Rinnai), blender turbo (Philips EHM-8099), sendok stainless, timbangan digital (QHC), panci, termometer, cabinet dryer (Omron), panci gagang (Jawa), ballon whisk, solet plastik, paper baking, dan loyang. Alat yang digunakan untuk analisis leather apel antara lain Digital Force Gauge (Imada), color reader (Konika Minolta), oven (Memmert), timbangan analitik (Denver Instrument M 310), desikator, kompor listrik (Maspion), muffle furnace (Thermolyne ${ }^{\mathrm{TM}}$ ), labu kjeldhal (Buchi), destilator (Buchi), buret, statif, soxhlet (Electrothermal), refluks, pompa vakum (KNF), shaker, tabung reaksi, pipet ukur $1 \mathrm{ml}$ dan $5 \mathrm{ml}$, pipet tetes, rak tabung reaksi, bulb, spatula, vortex, erlenmeyer $250 \mathrm{ml}$, dan spektrofotometer 20D Plus (Labomed).

\section{Desain Penelitian}

Eksperimen dilaksanakan dengan Rancangan Acak Kelompok (RAK) dua faktor, yaitu penambahan karagenan $(0 \%, 0.5 \%, 1 \%)$ dan penambahan tepung terigu $(1 \%, 2 \%, 3 \%)$. Setiap unit perlakuan dilakukan ulangan 3 kali sehingga didapatkan 27 satuan percobaan. 
Data yang diperoleh dianalisis dengan Analysis of Variance (ANOVA) untuk mengetahui pengaruh pada setiap perlakuan. Pemilihan perlakuan terbaik dilakukan dengan metode Desirability Function. Data hasil pengujian organoleptik dianalisis menggunakan uji Hedonic Scale Scoring.

\section{Tahapan Penelitian}

\section{Pembuatan Puree Apel Anna}

Apel Anna disortasi dan dikupas untuk menghilangkan bagian kulit dan dihilangkan bijinya. Daging buah apel Anna kemudian dicuci untuk membersihkan dari kotoran yang menempel dan dipotong menjadi bentuk dadu. Selanjutnya dilakukan steam blanching selama 3 menit dengan suhu $\pm 80^{\circ} \mathrm{C}$, kemudian dilakukan pendinginan. Setelah itu dilanjutkan penghancuran apel Anna menggunakan blender sehingga diperoleh puree apel Anna.

\section{Pembuatan Fruit Leather Apel Anna}

Puree apel Anna dicampurkan dengan gula pasir dengan rasio perbandingan (4:1). Ditambahkan karagenan $(0 \% ; 0.5 \% ; 1 \%)$ dan tepung terigu $(1 \% ; 2 \% ; 3 \%)$ sesuai konsentrasi yang telah ditentukan. Pemasakan adonan dilakukan selama 3 menit dengan suhu $\pm 80^{\circ} \mathrm{C}$ sambil diaduk. Pencetakan fruit leather dilakukan secara manual menggunakan solet plastik. Adonan fruit leather ditipiskan hingga ketebalannya $\pm 2 \mathrm{~mm}$. Pengeringan fruit leather menggunakan pengering kabinet dengan suhu $\pm 60^{\circ} \mathrm{C}$ selama 5 jam sehingga diperoleh fruit leather apel Anna.

\section{Prosedur Analisis}

Analisis penelitian ini meliputi analisis proksimat, yaitu kadar air, kadar lemak, kadar protein, kadar abu, dan kadar karbohidrat by difference (AOAC, 2005), aktivitas antioksidan (Molyneux, 2004), serat kasar (AOAC, 2005), dan tekstur (hardness, tensile strength, elongasi) (Yuwono dan Susanto, 1998).

\section{HASIL DAN PEMBAHASAN}

\section{Karakteristik Bahan Baku}

Bahan baku yang dianalisis adalah puree apel Anna (Malus domestica) yang telah diberi perlakuan pendahuluan dengan parameter yang dianalisia meliputi kadar air, kadar lemak, kadar protein, kadar abu, karbohidrat, serat kasar, dan aktivitas antioksidan. Data analisis bahan baku puree apel Anna ditunjukkan pada Tabel 1.

\begin{tabular}{|c|c|}
\hline Karakteristik & Hasil Analisis* \\
\hline Kadar Air (\%) & 86.86 \\
\hline Kadar Abu (\%) & 0.13 \\
\hline Kadar Lemak (\%) & 0.16 \\
\hline Kadar Protein (\%) & 0.76 \\
\hline Karbohidrat (\%) & 12.09 \\
\hline Serat Kasar (\%) & 1.09 \\
\hline Aktivitas Antioksidan $\mathrm{IC}_{50}(\mu \mathrm{g} / \mathrm{ml})$ & 3676.28 \\
\hline
\end{tabular}

\section{Kekerasan (Hardness)}

Hardness atau tingkat kekerasan merupakan gaya yang diperlukan untuk mengakibatkan perubahan bentuk (deformasi) pada produk. Hardness merupakan salah satu parameter penting pada evaluasi tekstur produk makanan. 


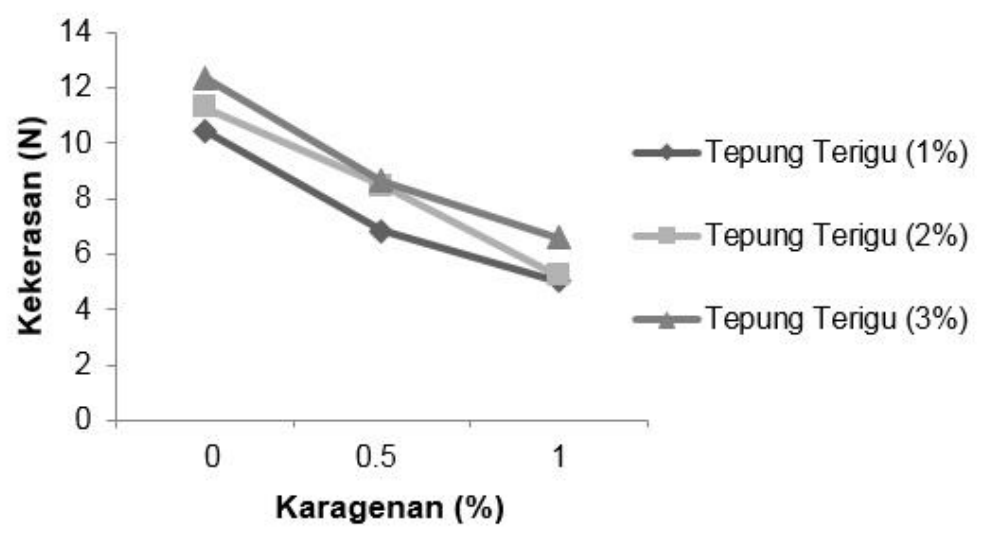

\section{Gambar 1. Pengaruh Konsentrasi Karagenan dan Tepung Terigu Terhadap Rerata} Kekerasan (Hardness) Fruit Leather

Hasil penelitian diperoleh bahwa penambahan konsentrasi karagenan semakin tinggi menyebabkan hardness pada fruit leather semakin menurun. Karagenan termasuk dalam kategori serat pangan larut air sehingga ketika terbentuk gel memiliki kemampuan mengikat dan memerangkap air dalam matriks pangan. Banyaknya air yang terperangkap akan menyebabkan kelembaban pada produk dan gel yang terbentuk memiliki tekstur yang lunak, sehingga kemampuan untuk menahan beban lebih rendah. Karagenan memiliki sifat higroskopis yang tinggi yang menjadikan molekul karagenan mampu berikatan kuat dengan air (Siregar et al., 2017).

Sedangkan semakin tinggi penambahan konsentrasi tepung terigu, hardness fruit leather semakin meningkat. Adanya interaksi antar polimer akan membentuk seperti lembaran film (sheet-like film) (Fitasari, 2009). Terbentuknya lembaran film (sheet-like film) yang terbentuk akan memperkuat struktur fruit leather. Semakin sedikit proporsi tepung terigu yang ditambahkan, kekerasan produk semakin rendah dan produk semakin mudah di patahkan (Istinganah et al., 2017).

\section{Kuat Tarik (Tensile Strength)}

Tensile Strength adalah beban maksimal yang dapat ditahan oleh sebuah bahan ketika diregangkan sebelum bahan terputus atau sobek. Semakin besar nilai tensile strength maka ketahanan terhadap gaya tarik akan lebih baik sehingga produk tidak mudah putus.

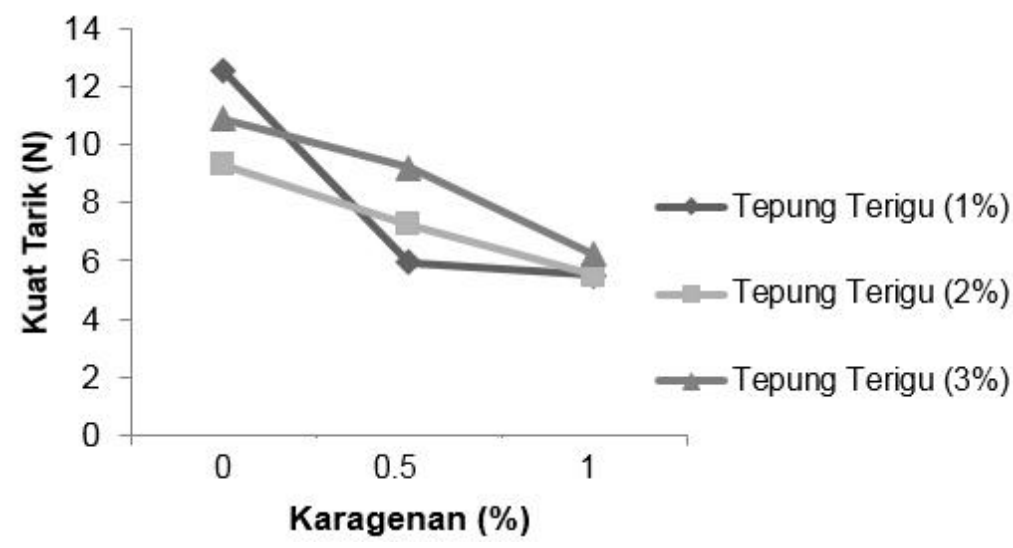

Gambar 2. Pengaruh Konsentrasi Karagenan dan Tepung Terigu Terhadap Rerata Kuat Tarik (Tensile Strength) Fruit Leather

Nilai tensile strength fruit leather semakin menurun seiring meningkatnya konsentrasi karagenan. Adanya gugus sulfat bermuatan negatif di sepanjang rantai polimer karagenan, menjadikan polimer ini memiliki kemampuan untuk mengikat air (Santoso, 2007). Adanya kandungan air yang terperangkap dalam produk seiring bertambahnya konsentrasi 
karagenan yang ditambahkan membuat antar ikatan tekstur fruit leather apel Anna lebih mudah lepas seiring gaya kuat tarik yang diberikan. Semakin tinggi kandungan sulfat pada produk akan menyebabkan peningkatan viskositas. Peningkatan viskositas berbanding terbalik dengan kekuatan gel, nilai viskositas yang semakin tinggi akan menyebabkan penurunan nilai kekuatan gel (Rasyid, 2003).

Sementara penambahan filler tepung terigu pada konsentrasi lebih tinggi menghasilkan nilai tensile strength yang semakin besar. Gluten dalam tepung terigu berfungsi sebagai pengikat dan menjadikan adonan bersifat elastis. Semakin rendah kandungan gluten yang terdapat dalam suatu bahan maka akan mengurangi sifat elastisitas bahan, sehingga bahan akan mudah putus apabila terjadi tekanan berupa tarikan atau regangan. Semakin sedikit jumlah tepung terigu dalam adonan mie akan menyebabkan penurunan sifat elastis (Rosalina et al., 2018).

\section{Elongasi}

Elongasi menunjukkan ukuran perubahan panjang yang terjadi pada spesimen yang disebabkan oleh adanya gaya yang diberikan (Stevens, 2001). Hasil penelitian diperoleh bahwa penambahan konsentrasi karagenan semakin tinggi maka elongasi produk fruit leather akan semakin rendah, sehingga fruit leather yang dihasilkan semakin tidak elastis.

Rendahnya nilai elongasi dapat disebabkan karena kappa karagenan membentuk agregat berupa jala-jala yang memiliki ikatan sangat kuat, sehingga penambahan karagenan akan mengakibatkan tekstur gel menjadi lebih keras dan rigid. Hal ini menyebabkan elastisitas gel yang semakin rendah karena gel semakin mengkerut dan bersifat mudah hancur atau pecah. Hasil penelitian mengenai pembuatan fruit leather pisang amabo menunjukkan bahwa kappa karagenan dapat menurunkan elastisitas produk (Marzelly, 2017). Pengaruh penambahan tepung terigu menunjukkan pada konsentrasi yang lebih tinggi menyebabkan elongasi fruit leather semakin tinggi. Saat tergelatinisasi komponen gluten akan berikatan dengan pati matrik yang lebih kuat, sehingga nilai tensile strength meningkat.

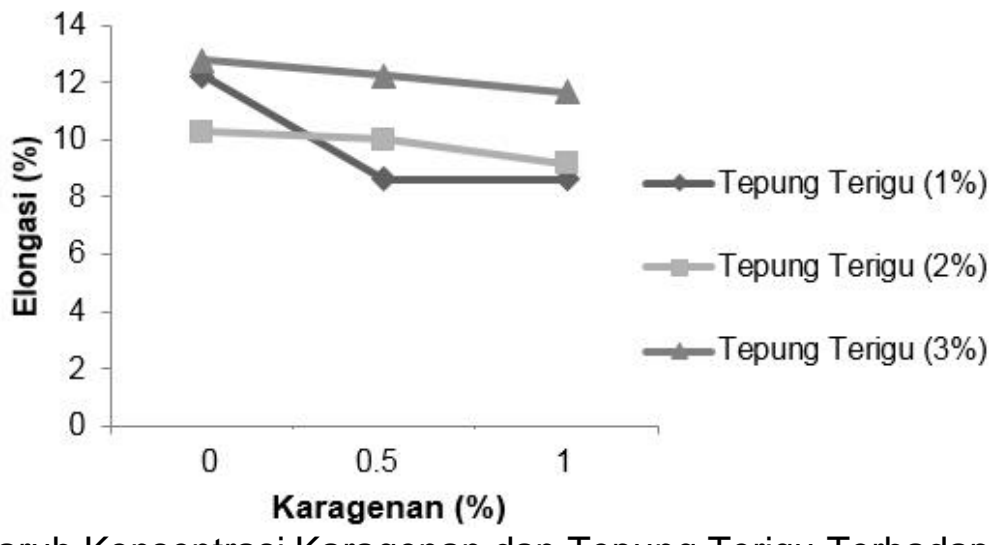

Gambar 3. Pengaruh Konsentrasi Karagenan dan Tepung Terigu Terhadap Rerata Elongasi Fruit Leather

\section{Kadar Air}

Kadar air didefinisikan sebagai persentase jumlah massa air yang terdapat dalam suatu bahan. Tekstur suatu produk pangan dipengaruhi oleh besarnya kadar air dalam produk. Hasil penelitian ini menunjukan bahwa penambahan konsentrasi karagenan semakin tinggi maka kadar air produk fruit leather akan semakin meningkat. Karagenan memiliki sifat emulsifier dan stabilizer yang berfungsi sebagai pembentuk gel. Karagenan memiliki kemampuan mengikat air yang besar dan mengakibatkan jumlah air bebas dalam gel juga meningkat. Karagenan dapat menahan air dengan baik, sehingga menyebabkan jumlah air yang diuapkan lebih sedikit dan kandungan air dalam produk lebih banyak. Penambahan karagenan pada produk pangan dapat meningkatkan daya ikat air (Ardianti et al., 2014). 
Penambahan tepung terigu pada konsentrasi lebih tinggi menyebabkan kadar air fruit leather semakin menurun. Pelepasan air yang semakin tinggi pada pembuatan fruit leather maka kadar air produk akan menurun. Pati dalam tepung terigu akan mengikat air, namun air yang terikat dalam pati lebih mudah diuapkan dan berkurang dalam proses pengeringan fruit leather, hal ini menyebabkan apabila kandungan tepung terigu tinggi maka kehilangan air pada proses pengeringan akan menjadi semakin cepat (Arief, 2008).

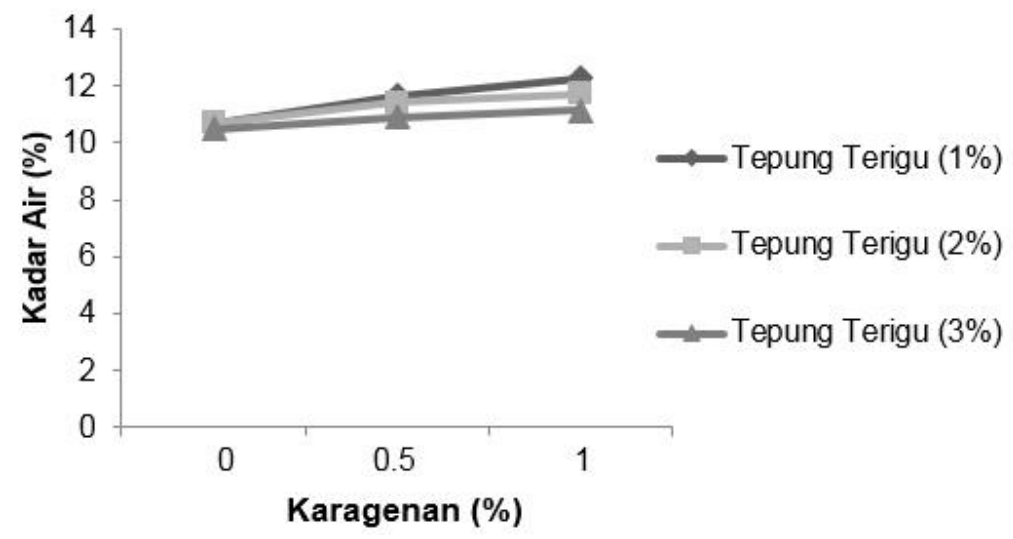

Gambar 4. Pengaruh Konsentrasi Karagenan dan Tepung Terigu Terhadap Rerata Kadar Air Fruit Leather

\section{Penentuan Perlakuan Terbaik}

Penentuan perlakuan terbaik fruit leather apel Anna dilakukan berdasarkan karakteristik fisik menggunakan metode Desirability Function (Malenovic et al., 2011). Produk komersial yang digunakan sebagai pembanding adalah umeboshi no sheet, dengan bahan dasar buah plum. Umeboshi no sheet diproduksi oleh iFactory Jepang, dibuat dari buah plum yang dihancurkan dan dipisahkan dari bijinya, kemudian ditambahkan gula dan garam yang selanjutnya diawetkan dengan cara dikeringkan. Parameter fisik digunakan sebagai respon untuk menentukan perlakuan terbaik. Parameter fisik dipilih karena fruit leather yang dihasilkan dalam penelitian ini memiliki kemiripan tekstur dengan produk komersial. Parameter fisik yang digunakan meliputi hardness, tensile strength, dan elongasi. Berdasarkan hasil perhitungan fruit leather dengan penambahan karagenan $1 \%$ dan tepung terigu 3\% merupakan perlakuan terbaik.

Tabel 2. Karakteristik Fisik Fruit Leather Apel Anna Perlakuan Terbaik dan Produk Komersial "Umeboshi no sheet iFactory"

\begin{tabular}{lccc}
\hline \multicolumn{1}{c}{ Karakteristik Fisik } & $\begin{array}{c}\text { Fruit Leather } \\
\text { Apel Anna }\end{array}$ & $\begin{array}{c}\text { Produk } \\
\text { Komersial }\end{array}$ & P - value \\
\hline Hardness $(\mathrm{N})$ & 6.60 & 3.4 & 0.002 \\
Tensile Strength $(\mathrm{N})$ & 6.22 & 15.86 & 0.001 \\
Elongasi $(\%)$ & 11.67 & 13.85 & 0.045 \\
\hline
\end{tabular}

Produk komersial memiliki karakteristik padat, kering, lunak dan mudah hancur. Komposisi produk komersial terdiri dari buah plum, gula (gula, fructose glucose liquid sugar), garam, pati, pemanis, (aspartame, L-phenylalanine compound, stevia), acidulant, seasoning (asam amino), sorbitol, dan pewarna (anthocyanins, carotenoids). Fruit leather apel Anna memiliki karakteristik kompak, kering, sedikit kenyal dan elastis. Komposisi fruit leather apel Anna terdiri dari puree apel Anna, gula pasir, karagenan dan tepung terigu. Jika dibandingkan dengan produk komersial yaitu Umeboshi no sheet iFactory berdasarkan Uji T ( $T$-test) terhadap nilai hardness diketahui adanya perbedaan yang signifikan terhadap produk komersial dengan nilai p $0.002(<0.05)$. Berdasarkan uji $T(T$-test) nilai tensile 
strength dan elongasi juga memiliki perbedaan yang signifikan terhadap produk komersial dengan nilai $p 0.001(<0.05)$ dan $0.045(<0.05)$.

\section{Karakteristik Fisikokimia Fruit Leather Perlakuan Terbaik}

Kadar air fruit leather perlakuan terbaik diperoleh sebesar $10.99 \%$. Rendahnya kadar air pada fruit leather apel Anna dapat disebabkan oleh proses pengeringan pada suhu $60^{\circ} \mathrm{C}$ selama 5 jam. Proses pengeringan menyebabkan air di dalam fruit leather menguap. Proses pengeringan dengan waktu yang relatif lama dan suhu yang tinggi maka evaporasi air dari produk akan tinggi dan menjadikan kadar air produk yang dihasilkan semakin rendah.

Hasil analisis kadar abu menunjukkan bahwa kandungan abu dalam fruit leather perlakuan terbaik sebesar $0.32 \%$. Sayur dan buah merupakan sumber nutrisi seperti vitamin, serat dan mineral. Mineral yang terkandung dalam sayuran dan buah-buahan berperan untuk membantu proses metabolisme dalam tubuh.

Hasil analisis kadar lemak terhadap fruit leather perlakuan terbaik menunjukkan nilai sebesar $2.25 \%$. Adanya penambahan tepung terigu diduga berpengaruh terhadap peningkatan kadar lemak pada fruit leather apel Anna. Selain itu, tingginya kadar lemak pada fruit leather apel Anna dapat diakibatkan oleh adanya proses pengeringan sehingga kadar air dalam produk menjadi rendah dan kadar lemak meningkat.

Tabel 3. Karakteristik Fisikokimia Fruit Leather Perlakuan Terbaik

\section{Karakteristik Kimia Fruit Leather Terbaik*}

\begin{tabular}{lc}
\hline Kadar Air (\%) & 10.99 \\
Kadar Abu (\%) & 0.32 \\
Kadar Lemak (\%) & 2.25 \\
Kadar Protein (\%) & 0.72 \\
Karbohidrat (\%) & 85.72 \\
Serat kasar (\%) & 3.47 \\
Aktivitas Antioksidan IC $_{50}(\mu \mathrm{g} / \mathrm{mL})$ & 5771.30 \\
Hardness (N) & 6.60 \\
Tensile Strength $(\mathrm{N})$ & 6.22 \\
Elongasi $(\%)$ & 11.67 \\
\hline \multicolumn{2}{c}{ Keterangan: *Setiap angka merupakan rerata 3 kali ulangan }
\end{tabular}

Kadar protein fruit leather perlakuan terbaik sebesar $0.72 \%$. Rendahnya kadar protein diduga karena proses destruksi yang kurang maksimal. Proses destruksi yang tidak maksimal akan menyisakan partikel padat yang masih mengandung nitrogen. Selain itu, tahap titrasi juga diduga menjadi faktor rendahnya protein pada fruit leather. Perubahan warna diukur secara kualitatif sehingga proses titrasi yang kurang tepat dapat mempengaruhi volume $\mathrm{HCl}$ yang digunakan untuk titrasi, hal ini dapat memberikan pengaruh terhadap perhitungan kadar protein pada sampel yang diuji.

Kadar karbohidrat pada fruit leather perlakuan terbaik yang sebesar $85.72 \%$. Proses pengeringan yang dilakukan akan menyebabkan hilangnya air pada fruit leather akibat adanya penguapan, sehingga total karbohidrat akan meningkat. Selain itu, penambahan tepung terigu dan gula juga berkontribusi dalam meningkatkan karbohidrat.

Jumlah serat kasar yang terkandung dalam fruit leather apel Anna perlakuan terbaik sebesar 3.47\%. Serat kasar merupakan komponen dari tumbuhan yang tidak larut dalam air. Analisis serat kasar membuat serat larut tidak dapat terhitung sehingga nilai serat pada fruit leather cukup rendah. Buah apel sendiri mengandung banyak pektin yang merupakan serat yang larut.

Hasil pengukuran aktivitas antioksidan fruit leather perlakuan terbaik yang dinyatakan dengan $\mathrm{IC}_{50}$ sebesar $5771.30 \mu \mathrm{g} / \mathrm{mL}$. Bahan baku fruit leather apel Anna adalah puree apel Anna yang telah dipisahkan dari kulitnya dan mengalami proses steam blanching. 
Antioksidan merupakan senyawa yang sensitif terhadap cahaya dan panas. Beberapa senyawa yang bersifat sebagai antioksidan biasa ditemukan dalam kulit apel, diantaranya adalah procyanidins, catechin, epicatechin, asam klorogenik, phloridzin, dan kuersetin (Boyer dan Liu, 2004).

Berdasarkan analisis tekstur menggunakan Digital Force Gauge fruit leather terbaik memiliki nilai hardness $6.60 \mathrm{~N}$, tensile strength $6.22 \mathrm{~N}$, dan elongasi $11.67 \%$. Fruit leather terbaik bersifat kompak, kering, sedikit kenyal dan elastis. Fruit leather apel Anna perlakuan terbaik memiliki kadar air 10.99\%. Bahan dengan kadar air lebih dari $10 \%$ berpotensi membentuk tekstur kenyal dan lunak, namun jika kadar air bahan di bawah $10 \%$ maka bahan akan mudah patah (Blahovec, 2007).

\section{SIMPULAN}

Berdasarkan parameter fisik yang diuji fruit leather apel Anna perlakuan terbaik yaitu dengan penambahan karagenan $1 \%$ dan tepung terigu $3 \%$. Nilai hardness, tensile strength dan elongasi mengalami penurunan seiring semakin tingginya konsentrasi karagenan. Karagenan merupakan hidrokoloid yang memiliki kemampuan mengikat air yang tinggi sehingga menyebabkan peningkatan kadar air produk fruit leather. Nilai hardness, tensile strength dan elongasi mengalami peningkatan seiring semakin tingginya konsentrasi tepung terigu. Adanya gluten pada fruit leather apel Anna menyebabkan terbentuknya tekstur yang elastis dan kompak sehingga tidak mudah robek. Fruit leather apel Anna perlakuan terbaik memiliki karakteristik kadar air $10.99 \%$, kadar abu $0.32 \%$, kadar lemak $2.25 \%$, kadar protein $0.72 \%$, karbohidrat $85.72 \%$, serat kasar $3.47 \%$, antioksidan $5771.30 \mu \mathrm{g} / \mathrm{ml}$, hardness $6.60 \mathrm{~N}$, tensile strength $6.22 \mathrm{~N}$, dan elongasi $11.67 \%$.

\section{DAFTAR PUSTAKA}

Agustin, F. dan Putri, W.D.R. 2013. Pembuatan Jelly Drink Averrhoa blimbi L. (Kajian Proporsi Belimbing Wuluh : Air dan Konsentrasi Karagenan). Jurnal Pangan dan Agroindustri 2(3): 1-9.

Ardianti, Y., Widyastuti, S., Rosmilawati, S.W., dan Handito, D. 2014. Pengaruh Penambahan Karagenan Terhadap Sifat Fisik dan Organoleptik Bakso Ikan Tongkol (Euthynnus affinis). Agroteksos 24(3): 159-166.

Arief, D. Z. 2008. Karakteristik Fish Leather Ikan Tongkol (Euthynnus Affinis) Dengan Konsentrasi Bahan Pengisi Dan Lama Pengeringan Yang Bervariasi. Infomatek 10:2, 113-120.

Association of Official Analytical Chemistry (AOAC). 2005. Official Methods of Analysis. Mc Graw Hill Press. Canada.

Badan Pusat Statistik Kota Batu. 2018. Jumlah Pohon Menghasilkan Dan Produksi Buah Menurut Jenis Tanaman di Kota Batu, 2016. https://batukota.bps.go.id/ statictable/2018/03/12/105/jumlah-pohon-menghasilkan-dan-produksi-buah-menurutjenis-tanaman-di-kota-batu-2016.html. Tanggal akses: 21/12/2018.

Baskara, M. 2010. Pohon Apel Itu Masih (Bisa) Berbuah Lebat. Majalah Ilmiah Populer Bakosurtanal - Ekspedisi Geografi Indonesia. Jawa Timur.

Blahovec, J. 2007. Role Of Water In Food And Product Texture. International Agrophysics $21: 3,209-215$.

Boyer, J. dan Liu, R.H. 2004. Apple Phytochemicals and Their Health Benefits. Nutrition Journal 3:5, 1-15.

Fitasari, E. 2009. Pengaruh Tingkat Penambahan Tepung Terigu Terhadap Kadar Air, Kadar Lemak, Kadar Protein, Mikrostruktur, Dan Mutu Organoleptik Keju Gouda Olahan. Jurnal Ilmu dan Teknologi Hasil Ternak 4:2, 17-29.

Historiasih, R.Z. 2010. Pembuatan Fruit Leather Sirsak-Rosella. Skripsi. UPN Veteran. Surabaya. 
Istinganah, M., Rauf, R. dan Widyaningsih, E.N. 2017. Tingkat Hardness Dan Daya Terima Biskuit Dari Campuran Tepung Jagung Dan Tepung Terigu Dengan Volume Air Yang Proporsional. Jurnal Kesehatan 10:2, 83-93.

Malenovic, A., Y. Dotsikas, M. Maskovic, B. J. Stojanovic, D. Ivanovic, dan M. Medenica. 2011. Desirability-Based Optimization and Its Sensitivity Analysis for The Perindopril and Impurities Analysis In A Microemulsion LC System. Microchemical Journal 99:2, 454-460.

Marzelly, A. D., Yuwanti, S. dan Lindriati, T. 2017. Karakteristik Fisik, Kimia, Dan Sensoris Fruit Leather Pisang Ambon (Musa Paradisiaca S.) Dengan Penambahan Gula dan Karagenan. Jurnal Agroteknologi 11:2, 172-185.

Molyneux, P. 2004. The use of the stable free radical diphenylpicrylhydrazyl (DPPH) for estimating antioxidant activity. Songklanakarin J. Sci. Technol. 26(2): 211-219.

Rascon-Diaz, M.P., Tejero, J.M., Garcia, P.G.M. and Garcia, H.S. 2010. Spray Drying Yogurt Incorporating Hydrocolloids: Structural Analysis, Acetaldehyde Content, Viable Bacteria, and Rheological Properties. Food and Bioprocess Technology 5:2, 560-567.

Rasyid, A. 2003. Alga Coklat (Phaeophyta) sebagai Sumber Alginat. Oseana 28:1, 33-38.

Rosalina, L., Suyanto, A. dan Yusuf, M. 2018. Kadar Protein, Elastisitas, dan Mutu Hedonik Mie Basah dengan Substitusi Tepung Ganyong. Jurnal Pangan dan Gizi 8:1, 1-10.

Santoso, D. 2007. Karakteristik Sosis Ikan Bawal Tawar (Colossoma macropomum) dengan Penambahan Karagenan. Skripsi. Institut Pertanian Bogor. Bogor.

Sidi, N.C, Widyowati, E. dan Nursiwi, A. 2014. Pengaruh Penambahan Karagenan pada Karakteristik Fisikokimia dan Sensoris Fruit Leather Nanas (Ananas comosus L. Merr.) dan Wortel (Daucus carota). Jurnal Aplikasi Teknologi Pangan 3:4, 122-127.

Siregar, J.A., Nainggolan R.J. dan Nurminah, M. 2017. Pengaruh Jumlah Karagenan Dan Lama Pengeringan Terhadap Mutu Bubuk Cincau Hitam Instan. Jurnal Rekayasa Pangan dan Pertanian 5:1, 89-95.

Stevens, M. P. 2001. Kimia Polimer. Pradnya Paramita. Jakarta.

Tawali, A.B. dan Zainal. 2004. Perubahan Mutu Buah Anggur Impor Pada Berbagai Suhu Penyimpanan. Jurnal Sains \& Teknologi 4:2, 72-82.

Yılmaz, F.M., Yuksekkaya, S., Vardin, H. and Karaaslan, M. 2017. The Effects of Drying Conditions on Moisture Transfer and Quality of Pomegranate Fruit Leather (Pestil). Journal of the Saudi Society of Agricultural Sciences 16:1, 33-40.

Yuwono, S.S. dan Susanto, T. 1998. Pengujian Fisik Pangan. Universitas Brawijaya. Fakultas Teknologi Pertanian Universitas Brawijaya. Malang. 